\title{
To Pay or Not to Pay? Evaluating the Belgian Law Against Vulture Funds
}

\author{
${ }^{1}$ Hasselt University, Faculty of Business Economics, BE-3500 Hasselt, Belgium \\ ${ }^{2}$ Hasselt University, Faculty of Business Economics, Martelarenlaan 42, BE-3500 Hasselt, Belgium, E-mail: \\ lode.vereeck@uhasselt.be
}

\begin{abstract}
:
Vulture funds are a grave problem for sovereign debt markets. Their uncooperative behavior delays the resolution of sovereign debt crises, inflicting harm on the economic health of financially distressed countries and consenting exchange bondholders. The unconventional ratable payment interpretation of the pari passu clause has strengthened their legal position. Various strategic, contractual, national and international remedies have so far proven ineffective. The most recent initiative, the Belgian Law Against Vulture Funds, establishes a variant of champerty by granting vulture funds nothing more than the purchase price, while allowing countries under attack of vulture funds to make payments to exchange bondholders via clearing houses in Belgium without the risk of attachment. This paper describes the Belgian anti-vultures law and its implications. We claim this law goes in the direction of improving the workings of sovereign debt markets. However, the Belgian bypass may lead to contempt of court in other jurisdictions, making it a costly and risky option for distressed countries. To be effective, the Belgian law should be part of a multilateral convention or adopted in other countries as a model law. Either way, it proves the need of an international framework.
\end{abstract}

Keywords: Belgian Law Against Vulture Funds, sovereign debt restructuring, sovereign default, vulture funds JEL classification: F34, H63, K33

DOI: $10.1515 /$ jgd-2017-0010

\section{Introduction}

"When it becomes necessary for a state to declare itself bankrupt, in the same manner as when it becomes necessary for an individual to do so, a fair, open, and avowed bankruptcy is always the measure which is both the least dishonourable to the debtor, and least hurtful to the creditor." ${ }^{1}$

Two and a half centuries ago, Adam Smith (1776) noticed that sovereign defaults, however undesirable, are a fact of economic life and require a swift solution at the lowest cost for the creditors as well as for the debtor state and its citizens. Sovereign debt restructuring (SDR) is, however, fundamentally different from corporate restructuring for the lack of a clear legal framework. There are no compulsory bankruptcy proceedings protecting creditors, nor sovereign debtors, yet it is not really possible to liquidate them either. A sovereign default thus entails complex negotiations that can easily break down. In the corporate context, bankruptcy laws provide an orderly procedure that may allow for an increase in the "going-concern" value of the firm. In public restructurings, the interests of the sovereign, i.e. reelection thanks to the increased welfare of the people, do not naturally coincide with the creditors' interests, i.e. collecting the full value of the distressed debt.

In recent history, the prevalence of vulture funds has unsettled the SDR process. Vulture funds can be defined as investment funds, often located in offshore tax havens, that purchase sovereign debt on the secondary market from mostly poor countries in financial distress at a significant discount. They do so with the intention to collect the full value of the debt (i.e. the face value plus interests and fines) and reap exorbitant profits, typically via litigation in domestic and foreign courts. Another driver for vulture funds to litigate is not to win and get repaid in full, but to profit from credit default swaps (Venengo 2014: 47). Holdouts then have a perverted interest in a default, instead of a solution (Brooks et al. 2015). Between 1976 and 2010, the number of unique lawsuits against sovereign debtors in default has gone up from less than five in the 1980s, to more than forty disputes in more recent years (Schumacher, Trebesch, and Enderlein 2014). In total, 109 lawsuits were launched (Das, Papaioannou, and Trebesch 2012).

The rise of vulture funds and litigated SDR coincides with the development of a secondary market in sovereign bonds. After the Latin American debt crisis, the market was transformed from syndicated loans to 
bond financing (Buchheit and Reisner 1988). As a result, creditors became far more numerous and a secondary market emerged. ${ }^{2}$ This atomistic market created problems of collective action in debt restructuring. Atomized creditors have much more divergent interests, that are more likely to lead to litigation against sovereign debtors. By contrast, institutional lenders prefer to participate in a collective restructuring instead of holding out. Furthermore, the trimming of sovereign immunity, which started in 1976 by the Foreign Sovereign Immunities Act (FSIA), also opened new doors for vulture funds eager to litigate.

Vulture funds undermine the functioning of the international financial markets for sovereign debt by discouraging rational investors from cooperatively participating in restructuring efforts. Their holdout strategy not only complicates the resolution of sovereign debt crises, it also inflicts social and economic harm on the financially distressed countries as well as the consenting restructured bondholders. Many solutions to this grave problem have been put forward. The purpose of this paper is to assess the practicability of the Belgian Law Against Vulture Funds, that establishes a variant of the champerty defense, that, if applied, would eradicate the vulture funds. The paper is structured as follows. The second and third paragraph briefly describe the role of vulture funds and the game-changing Argentine sovereign debt default of 2001. The fourth paragraph discusses the (in)effectiveness of the various strategic, contractual, national and international proposals to solve the problem of vulture funds. The latest initiative, the Belgian Law Against Vulture Funds, outlaws the disproportionate rewards of vulture funds and bypasses the hold-up of payments to restructured bondholders. The use and limitations of this radical legal proposal are discussed in the fifth paragraph. The last paragraph offers the main policy conclusions.

\section{Vulture Funds}

Vulture funds are widely criticized for their usurious profits, although their lucrative business is perfectly legal under contract law. Admittedly, a positive role of vulture funds is to provide liquidity to the secondary market and offer financial relief to primary creditors seeking to exit. Without any doubt, they are entitled to a fair and competitive compensation for doing so. The public debate, however, is about the disproportionate reward. Vulture funds would still make huge profits if they would settle on the same terms as the exchange bondholders. Yet, as they press for the full value, they impose costs on the distressed countries that are beyond the benefits of providing liquidity to the secondary market. ${ }^{3}$

In their own defense, vulture funds often argue that they expose corruption and promote transparency in countries to the benefit of citizens and investors (Muse-Fisher 2014). The argument cuts no ice, since the vulture funds are more than willing to settle with the corrupt regimes they supposedly expose. Also, they are said to uphold the rule of law and punish distressed-debt countries for breaking their contract. The argument is void too, since vulture funds typically invest after a country's (expected) default. Their post-default actions are purely speculative and add no value to the real economy. Furthermore, the argument that vulture funds lower the costs of capital is not supported by empirical evidence (Eichengreen and Mody 2000). Finally, debt defaults and restructurings allow the international debt market to continue working. Vulture funds complicate future voluntary and cooperative restructurings of sovereign debt, since they discourage rational investors from participating in restructuring efforts and undermine the functioning of international financial markets for sovereign debt, which in turn undermines the ability to borrow and grow.

Finally, vulture funds have been described as the "avenging angels" of public debt necessary to make the financial markets operate effectively (Bosco 2007: 36). In reality, they are not primary stakeholders, but hurting the primary creditors who suffer from a prolonged restructuring process and a lower settlement. Clearly, the protracted litigation by the holdouts that bars countries from access to the international capital markets, is not a sustainable model.

\section{The Argentine Landmark Case}

The largest sovereign default in international financial history at that time happened in Argentina in 2001: a default on approximately US\$94 billion, a 70\% haircut and hundreds of lawsuits that followed. ${ }^{4}$ More important though is its precedent value that has changed the legal interpretation of long-established legal concepts. Moreover, its outcome will probably impact on future SDRs and the functioning of the international sovereign debt market.

In 2005, Argentina settled with approximately $76.15 \%$ of its bondholders, who were willing to exchange their defaulted bonds for new bonds, worth 30 cents on the dollar. ${ }^{5}$ In 2010, the Argentine Congress temporarily suspended the "Lock Law" $^{6}$ to allow for a second negotiation round in which another $16 \%$ of bondholders 
participated. 92.4\% of all bondholders thus accepted a deal with the Argentine government. The remaining $7.6 \%$ of holdout bondholders refused to settle and opted instead to litigate for the full value of an estimated US\$ 6.3 billion of defaulted bonds (Guzman 2016).

The linchpin of holdout litigation is enforcement as the property of the state enjoys immunity from execution to the extent that it serves public functions. In the past, bondholders won judgments against Argentina, but found it difficult to enforce them as the Argentine state had next to no attachable property on American soil or elsewhere abroad. For that reason, they looked for an enforceable alternative by relying on the pari passu clause and targeting the payments which Argentina makes to its cooperative creditors. Traditionally, the pari passu clause is understood as a contractual provision that required the equal ranking and treatment of creditors. In the Argentine case, the Southern District Court of New York surprisingly interpreted it as a prohibition to pay the exchange bondholders without making "ratable" payments in full to the holdout bondholders. ${ }^{7}$ This interpretation contradicted the traditional view which relates to legal subordination of rights and does not require ratable payments. Yet, it is largely identical to the infamous 2000 ruling by the Brussels Court of Appeal that decided that the pari passu clause required Peru to make a ratable payment to all creditors. The court in Brussels also prohibited payments by the Belgium-based clearing house Euroclear to exchange bondholders trying to circumvent its ruling. However, the latter part of the decision was overruled in 2004 by the same Brussels court that this time opined that the pari passu clause could not be used against an intermediary because it was not a party to the contract. ${ }^{8}$ The Belgian Parliament agreed and thus speedily passed a law that forbade such injunctions against intermediaries that would frustrate the efficient functioning of capital markets. ${ }^{9}$ Nevertheless, the significance of the 2000 Belgian court decision can hardly be underestimated: it marked the birth of the ratable payment interpretation of the pari passu clause (Turchi 2015: 2194) which allows holdouts to interfere with payments to third parties, i.e. the exchange bondholders, rather than trying to attach sovereign assets (Samples 2014: 58).

This interpretation was confirmed by a ruling of the United States Court of Appeals for the Second Circuit in October 2012. The higher court upheld the district court injunction that forced Argentina to pay the holdout bondholders the full value of their defaulted bonds, whenever it made a payment to its exchange bondholders. Additionally, the Southern District Court of New York ruled that intermediaries were forbidden from making payments to the exchange bondholders without paying the holdout bondholders. When the intermediary Bank of New York Mellon missed a bond payment - as it was caught between its role as a trustee of the Argentine Republic and the court orders - a deadlock occurred that plunged Argentina into "selective" default. It is important to note that this injunction also prohibited to pay exchange bondholders via foreign banks.

In February 2016, the new Argentine government decided to cut a deal and pay the vulture funds $75 \%$ of their original claim (Porzecanski, Devereux, and Van Voris 2016). To do so, Argentine Congress had to repeal two laws, the Lock Law and the Sovereign Payments Law. ${ }^{10}$ This event triggered the reversal of the injunctions prohibiting Argentina from paying the exchange bondholders and allowed Argentina to return to the international credit markets. The main vulture fund made a staggering return of $1180 \%$ (Guzman and Stiglitz 2016a).

The economic and international fall-out of the Argentine case was considered "terrible news for the rest of the world," especially for countries that might face a debt default in the future, since it encourages other funds to hold out and makes future debt restructuring virtually impossible (Guzman and Stiglitz 2016a).

\section{Solutions for an Orderly SDR Process}

The transformation from syndicated lending by banks to bond financing by millions of small investors created an atomistic market prone to litigation. One obvious solution is to return to syndicated lending. Banks can indeed solve the collective action problem at lower costs and collectively impose sanctions on default. In the past, negotiations after default would take place with only one Bank Advisory Committee. Obviously, it is easier to coordinate a few banks than thousands of creditors, thus avoiding protracted and litigated debt restructurings. Banks that would seek to free-ride by single-handedly settling with the defaulting state could be punished by exclusion from the syndicate and future lending. However, this solution is also likely to create welfare costs, since syndicated lending creates a cartel offering oligopolistic banks an above-market profit.

The essence of the problem with SDR is not the presence of atomistic investors as such, but rather the lack of a bankruptcy procedure that protects the interests of debtors and creditors. There are no clear-cut legal procedures to enforce payments by a state that has defaulted on its debt obligations. In recent years, various strategic, contractual, international and national solutions for an orderly SDR process have been put forward by international organizations, policy-makers and legal scholars, which will be discussed in the next paragraphs. 


\subsection{Strategic Solutions}

Apart from political and military pressure in the past (Tomz 2007), creditors can always threaten defaulting states with informal sanctions to deter opportunistic default and restructuring. Creditors can threaten sovereigns with a lawsuit or with "economic dislocation," i.e. the blocking of the IMF and the World Bank acting as lenders of the last resort to nations struggling with financial insolvency or illiquidity (Shalolashvili 2015: 192). Since financially distressed nations have a strong incentive to stay out of economic dislocation, they are indirectly forced to settle at reasonable terms (Eaton and Gersovitz 1981). Sovereigns are also worried about reputational damage due to a protracted and litigated SDR, since they cannot borrow money to finance investment projects if creditors threaten or effectively uphold a lending embargo.

A novel way to overcome the ratable payment interpretation of the pari passu clause is the "cryonic" solution (Buchheit and Gulati 2017). Instead of exchanging old bonds for new bonds, the sovereign debtor holds on to the old bonds for strategic reasons with the help of a trustee. If the sovereign is attacked by vulture funds, the trustee can threaten to demand a ratable payment on his old bonds (equal to the level of the new bonds), to which the sovereign obliges. Any proceeds can be used to pay the exchange bondholders.

\subsection{Contractual Solutions}

While it may be in the best interests of creditors as a group to cooperate and restructure the defaulted debt as soon as possible, individuals might have an incentive to hold out and block the solution unless they are paid in full. A formal solution to overcome the deadlock created by holdout creditors is the inclusion of a "collective action clause" (CAC) into sovereign bond contracts that permits a supermajority of bondholders (typically $75 \%$ ) to change the key financial terms of the bond for all creditors, thus binding the holdouts and allowing an orderly restructuring. It follows that vulture funds can no longer claim the full value of the bonds purchased at a discount price if the supermajority accepts a haircut.

CAC's are commonplace in bonds governed under New York law since February 2003 and have become standard market practice. Although CAC's have mitigated the collective action problem, they have not eradicated the holdout problem. The threshold requirements often appear to be high and impractical. ${ }^{11}$ Since CAC's operate on a series-by-series basis, they allow vulture funds to easily acquire a blocking position in a specific bond series. Their position had even strengthened by the New York court decisions. The aggregation of claims across bond series for voting purposes may bind all bondholders of all series to a restructuring plan. It is primarily used for restructuring domestic debt, since aggregation for international sovereign debt is limited by a two limb voting structure, which requires a minimum level of support $(66.67 \%)$ in each series and across series (International Monetary Fund 2014: 18-19). The next step is one limb voting procedure that safeguards smaller bondholders from discrimination by larger bondholders. Still, the potential exchange bondholders will continue to be faced with substantial transaction costs in setting up the collective action with other creditors and in negotiating an agreement that holds a supermajority.

The alternative mechanism of "exit consents" enables a majority of bondholders participating in an exchange bond negotiation to alter the nonpayment terms of the defaulted bonds, thus rendering the old bonds less valuable and less attractive for holding out. While exit consents are helpful in stimulating participation in restructuring, they cannot completely prevent litigation if the "buoying-up" effect of the restructuring is greater than the value decrease by the exit consents (Broomfield 2010: 497-498).

Another method to incentivize bondholders to participate in debt restructuring is to offer them contractual "sweeteners" such as mandatory prepayment clauses or mandatory restatement of principle clauses, ${ }^{12}$ creditlinked notes, a guarantee, the use of principal defeasance or of collateral. Recently, the use of "trigger" clauses was proposed which automatically extend the maturity by three years when a country is in financial distress (Weber, Ulbrich, and Wendorff 2011). Contractual sweeteners are effective if their fixed return outperforms the expected return of litigation. Given the Argentine precedent, the chances are slim.

Offering holdouts nothing more, nothing less than the exchange bondholders (as Argentina did in March 2013) meets the conventional pari passu provision that simply prohibits the legal subordination of some creditors. It also offers the holdouts a profitable remedy without disincentivizing investors to participate in restructuring efforts. Therefore, the Regulatory Policy Committee of the International Capital Market Association recently created a standardized pari passu clause that prohibits any conditioning of payments upon the payments to other obligations and specifically denies any obligation to make ratable payments to other creditors (International Capital Market Association 2014). Consistent with ICMA, the IMF has proposed a reform of the pari passu clause that reestablishes the traditional view as a prohibition to legal subordination and also excludes the obligation to make ratable payments to holdout creditors (International Monetary Fund 2014). Although a return to the conventional pari passu clause may weaken the position of vulture funds in court, it is not going to stop them from litigating. 


\subsection{International Solutions}

Since vulture funds act globally, an international approach is widely recognized as the first-best solution to handle sovereign defaults (Guzman and Stiglitz 2016b). In 2002, the IMF introduced the Sovereign Debt Restructuring Mechanism (SDRM) (Krueger 2002). Based on the best practices in corporate insolvency laws, the SDRM proposal included the following features: (1) a stay during the restructuring negotiations, (2) measures to protect the creditors' interests during the stay, (3) measures to provide new financing to the debtor during the stay, and (4) a provision that binds all creditors once an agreement has been reached by a qualified majority. More recently, the new Sovereign Debt Adjustment Facility (SDAF) makes bailing out of countries by the IMF contingent upon debt restructuring, while at the same time protecting countries that engage in an orderly restructuring (Buchheit et al. 2013).

Another proposal is the creation of a permanent international bankruptcy court, that would have the authority to approve tailor-made restructuring plans. The International Centre for Settlement of Investment Disputes (ICSID) at the World Bank can be considered as an example of an international tribunal. In 2011, it heard its first case on sovereign public debt. Since then, the tribunal has been plagued by the problems encountered in almost any court system: lack of enforcement power and court delay. However, the ICSID is more an arbitration platform for investment disputes, which offers only procedural rules and no substantive law. Nevertheless, the model may inspire the creation of a genuine international bankruptcy court with expert judges at, for example, the Permanent Court of Arbitration in The Hague (Paulus 2012: 12).

A more modest solution is an International Board of Certification (IBC) for sovereign-debt restructuring proposals (Pottow 2013). The IBC would assess in broad terms whether a restructuring proposal meets the international customary standards of fairness, laid down in a code of conduct for restructuring sovereign debt. ${ }^{13}$ Based on the certification by an IBC, courts could re-invoke comity and adopt a reverse-injunction rule, that would enjoin the actions of holdout creditors until after the exchange bondholders are paid. As such, it can be considered "soft" international law.

In 2014, the General Assembly of the United Nations adopted with an overwhelming majority a resolution to start a negotiation process to set up a multilateral framework for restructuring sovereign debt. A resolution was approved by the General Assembly in September 2015, ${ }^{14}$ installing soft law that establishes nine principles of SDR: sovereignty, good faith, transparency, impartiality, equitable treatment, sovereign immunity, legitimacy, sustainability and majority restructuring.

Creating worldwide consensus necessary for international law has proven immensely difficult. Due to the political resistance to transfer bits of national sovereignty to an international body, international solutions are not working today or are simply too soft to enforce a remedy and settle disputes.

\subsection{National Solutions}

In the first cases of sovereign debt litigation, a strong defense was "champerty," which considers as an abuse of court the purchase of debt with the sole purpose of litigating. If the courts had endorsed this argument, it would have ended sovereign debt litigation. Unfortunately, the Second Circuit held that if the plaintiff had a double strategy of purchasing the debt to be paid in full or otherwise suing, the champerty argument did not apply. ${ }^{15}$

In 2006, the French Assembly discussed a bill to stop holdout creditors from undermining the debt relief efforts of the French government. ${ }^{16}$ Built on the champerty doctrine, the law proposal prohibited French courts to make a ruling or to enforce the decisions of foreign courts in favor of vulture funds. It also allowed primary creditors to buy back the debt under litigation at the actual purchase price plus fair expenses and interests. However, the French Parliament rejected the law fearing that the champerty criterion was too vague and subjective and that the law would also harm the other better-intended creditors that tried to ensure payment via litigation (Bai 2013: 723). Three years later, there was a failed attempt to pass the comprehensive Stop VULTURE Funds Act in U.S. Congress. ${ }^{17}$ The law would have criminalized sovereign debt "profiteering" of poor countries, ${ }^{18}$ which was defined as collecting more than $6 \%$ interest. It would also have prohibited U.S. courts from hearing claims by vulture funds.

In 2010, the UK parliament successfully passed the Debt Relief (Developing Countries) Act which was applied retroactively and limited to highly indebted poor countries (HIPC).$^{19}$ The law sets a cap on repayments in accordance with HIPC debt relief. Excluded from protection are short-term debts and liabilities for goods and services. This way, it seeks to mitigate moral hazard behavior by the debtor state. Furthermore, it makes its protection contingent upon genuine engagement in debt restructuring and relief efforts.

A bold, but controversial step in fighting off vulture funds is addressing the illegitimate character of the sovereign debt (Cantamutto and Ozarow 2016). Since a nation's budget is a law that authorizes the government to tax, spend and borrow, it requires parliamentary approval. Without the latter's consent, the financial activities 
of the government are illegal. A public audit of a nation's loans should assess whether the debt issuance was illegitimate or illegal, which would destroy the value of the bonds. However, the bulk of sovereign loans is emitted upon formal parliamentary consent.

Due to their limited scope, national initiatives have not eliminated the incentives for vulture funds to sue and attack countries in financial distress. Actually, none of the SDR proposals discussed above have proven to be effective remedies to fight off vulture funds. ${ }^{20}$ Neither collective action clauses (that can easily be circumvented by acquiring a strategic blocking minority), nor contractual sweeteners (that offer a too low return compared to holding out) are deterring them. Nor will (a return to) the conventional pari passu clause eliminate their activities, although it might weaken their position in court. It is true that an international procedure is the most effective way to unblock the stranglehold maintained upon both exchange and holdout bondholders. However, a soft, let alone a hard international solution is unlikely to materialize since it is also plagued by rational non-cooperative behavior by states. Waiting for an international consensus is like waiting for Godot. Therefore, a combination of contractual, international, and national solutions would actually be the most promising way forward in the short run, absent a treaty solution that might change practice in the long run (Bohoslavsky and Goldmann 2016; Howse 2016). Therefore, Belgium took a new initiative, establishing a modern variant of champerty, that can be considered as part of a larger puzzle of incremental improvements.

\section{The Belgian Law Against Vulture Funds}

In 2008, the Belgian parliament had already proven its willingness to take the steps necessary to limit the activities of vulture funds, After the outrage over the seizure of public funds intended for two Belgian development projects in the Republic of Congo-Brazzaville, parliament passed a law to reinforce sovereign immunity by protecting money for development aid and debt relief from attachment by vulture funds. ${ }^{21}$ However, the law had two major flaws. First, public money that was not intended for development aid was not immune from attachment and, second, all creditors were targeted, including (non-vulture) funds that pursued legitimate goals. The law was simply not good enough.

\subsection{Content}

On January 14,2015, a group of Belgian politicians, political advisors and scholars gathered at the headquarters of a non-governmental organization in Brussels. ${ }^{22}$ This "coalition of the willing" agreed on the text of a bill that would entitle vulture funds to no more than the reimbursement of the purchasing price of the distressed bonds. Next, the proposal was sent to the Belgian House of Representatives, that expeditiously reached full agreement and submitted the text to parliament on April 30. On May 6, 2015, the bill was officially signed by the members of the parliamentary Finance Committee. The formal discussions took place in the Finance Committee on May 20 and June 9 and in the plenary sessions of May 25 and July $6,{ }^{23}$ where it passed with unanimous consent. On September 11, 2015, the law appeared in the Belgian Gazette, proving that a multi-party democracy can operate swiftly and effectively when democratic consensus is carefully crafted.

During the formal discussion, the Belgian members of parliament pointed out that although an international solution is preferable, a national law may set an example and expedite international action. In the preliminary memorandum, they wrote: "If the text to be adopted proves effective, it can serve as a model for larger national and international legislative initiatives." Hence, the Belgian legislators urged the Belgian government to convince its European counterparts to adopt their model-law (Schwarcz 2015), hitherto unsuccessfully.

The main article of the law states:

"When a creditor pursues an illegitimate advantage by purchasing a loan or debt from a state, his rights with regard to the debtor state are limited to the price he has paid to purchase that loan or debt. [...] The pursuit of an illegitimate advantage can be deduced from the existence of a manifest disproportion between the purchasing price paid by the creditor and the face value of the loan or debt, or between the purchasing price paid by the creditor and the sums he is claiming. To prove the illegitimate advantage [...], the manifest disproportion has to be complemented by at least one of the following criteria:

1. the debtor state is in a proven or imminent state of insolvency or suspension of payments at the moment the loan or debt is purchased;

2. the creditor has its headquarters in a tax haven [...]

3. the creditor makes systematic use of legal procedures to obtain the reimbursement of the loan(s) he has previously purchased; 
4. the debtor state has been involved in a process of debt restructuring, at which the creditor refused to participate;

5. the creditor has abused the weak position of the debtor state to negotiate manifestly unbalanced terms of repayment;

6. the full repayment of the sums claimed by the credit will have a proven unfavorable effect on the public finances of the debtor state and is susceptible at compromising the socio-economic development of its population."

If a Belgian court finds a fund acting as a "vulture," the latter cannot claim more than the discounted price it paid. Anything above the purchasing price is deemed illegitimate. So first, the judge must demonstrate an "illegitimate advantage" for the vulture fund, which can be deduced from the manifest disproportion between the purchase price and the face value of the debt purchased. Although the law does not specify a mathematical formula, the concept of "illegitimate advantage" is clearly defined in the law and well-established in Belgian legal tradition. Art. 1699 of the Belgian Civil Code neutralizes damaging and speculative transactions, stating that a party against whom a legal claim is transferred, can get rid of that claim by compensating the transferee the actual transfer price plus legal costs and interests. Moreover, in a verdict by the Belgian Court of Cassation, abuse of Justice is said to occur when the execution of a legal right manifestly exceeds the boundaries of a normal use by a prudent and thoughtful person. In other words, the judge has to assess the proportionality of enforcing the right.

Second, a Belgian judge has to additionally prove that the creditor is also meeting at least one of the six 'vulture' criteria. The first criterion, i.e. the imminent or realized insolvency is meant to counter speculative abuse of the other party's (temporary) weakness. The second criterion is residing or being incorporated in a tax haven. The third criterion is the systematic use of legal procedures, which is like the trademark of the vulture funds. The fourth criterion is the obstruction of debt restructuring efforts, especially by international organizations. The fifth criterion is the disadvantaging of the counterpart by obtaining procedural or contractual advantages. The sixth criterion is the unfavorable impact on the public finances of the debtor nation and the welfare of the population. Debt sustainability, which is nowadays considered as a "soft" principle of international public law (Bohoslavsky and Goldmann 2016) is thus adopted in the "hard" Belgian legal order, where it can be tested by domestic judges.

The Belgian law thus promotes fair instead of full repayment of public debt in case of a default. Inspired by the French example, it builds on the champerty doctrine, which presupposes the intent to litigate and requires proof of intentional abuse of court. Under the more pragmatic Belgian law, the pursuit of an "illegitimate advantage by purchasing a loan" is illegal when combined with the systematic, not the intentional use of "legal procedures to obtain the reimbursement of the loan(s)."

\subsection{Purpose and Practicability}

The Belgian legislators were convinced that the law of July 2015 would effectively countervail the vulture funds by outlawing their illegitimate activities. The law offers a Belgian bypass to countries unable to service their agreements with a supermajority of their creditors, due to the infamous ratable payment interpretation of the pari passu clause. In practice, this means that debtor states can pay their restructured bondholders via Belgium without the risk of attachment by vulture funds. Yet, how practicable is the law? Argentina, for instance, did not take this route, apparently since the law came into effect two months before the presidential elections, i.e. too late for the former administration (while the new government had already decided to settle). Nevertheless, the main American hedge fund, NML Capital, took to the Belgian Constitutional Court to have the law repealed after it won the stalemate with the Republic of Argentina, ${ }^{24}$ proving that the law is considered at least a threat to their business.

Solving the deficiencies of the current SDR non-system really requires a multinational framework, either of hard law or, if not feasible in the short run, of incremental soft law (Guzman and Stiglitz 2016c). Any proposal, including the Belgian initiative, should thus be evaluated in terms of its respect for the basic principles laid down in the 2015 United Nations resolution: sovereignty, good faith, transparency and impartiality, equitable treatment, sustainability, majority restructuring, legitimacy and sovereign immunity. Undoubtedly, the Belgian law restores the sovereign right of states to restructure their debt, which is violated by vulture funds strengthened by some unconventional US court decisions. Under Belgian law, only manifestly "disproportionate" rewards are outlawed, which also protects exchange bondholders that participate in restructuring efforts in good faith and incentivizes sovereigns and vulture funds to do the same. The transparency and impartiality of the procedure are guaranteed by the court system that will grant transferees equal and equitable compensation, i.e. in line with the Belgian legal tradition on speculative transactions. Limiting the reward of vulture funds to the transfer price (plus legal costs and interests) also restores the sustainability of the restructured debt. But may it infringe on the equal treatment relative to exchange bondholders? Clearly not, holdouts are free to accept the conditions 
of the restructured bonds accepted by the majority. By doing so, they no longer qualify as vulture funds, while still making a huge return on investment. If the law would automatically grant a price equal to the restructured bonds, it would have no deterrent effect and create unequal treatment among other transactions pursuing illegitimate advantages (Art. 1699 of the Belgian Civil Code).

The principle of legitimacy forbids that any debt restructuring violates the constitution or any human right. During the debate in Parliament, it was questioned whether the law was in conflict with article 1 of Protocol no. 1 to the European Convention for the Protection of Human Rights and Fundamental Freedoms on the protection of property rights. However, since this law does not expropriate the hedge funds, article 1 simply does not apply. Moreover, the second paragraph of article 1 clearly states that a nation has the right to organize the use of property rights in accordance with general welfare, while article 17 explicitly prohibits the abuse of treaty dispositions. The Belgian law not only promotes the general welfare of people living in countries under financial distress, it is also proportionate since the reduction of the claim is precisely meant to counter a manifestly disproportionate claim. Finally, the Belgian law also protects sovereign immunity, which came under fierce attack, as will be explained in the next paragraph.

\subsection{Rent-Seeking}

Soon after the signing of the law proposal during the press conference of May 6, 2015, strong and rising pressure emerged from national and international financial lobbying groups. The Belgian Financial Sector Federation, FEBELFIN, representing the banks and niche players wrote a letter to the parliamentary Finance Committee proposing an amendment that would exempt its regulated members. Given that the latter have a banking license and are under the regulatory supervision of the National Bank of Belgium, FEBELFIN claimed that they automatically "do not pursue an illegitimate advantage." The organization also warned for liquidity problems on the secondary market. The members of parliament rejected the argument as corporatist rent-seeking.

The National Bank of Belgium also wrote a public letter on June 4, 2015 to the Minister of Finance, in which it (1) pleads for an international initiative, (2) refers to the existing Belgian laws on sovereign immunity, (3) warns for the potentially negative effects on legal certainty, in particular the possible infringements on the European Convention on Human Rights and Personal Freedoms, and on the functioning of secondary market for public debt instruments, (4) expresses its fears that Belgian financial institutions might get squeezed between contradicting court orders in Belgium and abroad, and (5) requests a mathematical formula to establish "the manifest disproportion between the purchasing price paid by the creditor and the face value of the loan or debt." None of the arguments was strong enough to substantially alter, let alone repeal the law. The first argument in favor of an international initiative was recognized as genuine, but not going to be achieved in the short run; the second argument just confirmed the need for this broader initiative beyond the protection of the Belgian development aid funds; the third argument was countered by the legal arguments discussed above; the fourth argument of judicial "squeeze" was redressed via an amendment; and finally, although the concept "illegitimate advantage" is not put in a mathematical formula, the Belgian law does provide a guideline since the reimbursement of the purchase price plus interests and legal costs is explicitly mentioned as legitimate. Moreover, the legal criteria for identifying a vulture fund are drafted in a way that the law does not cover well-intended banks.

Finally, the Institute of International Finance (IIF) wrote a letter to the Chairman of the parliamentary Finance Committee on May 19, 2015, expressing its fears that (1) the "inaccurate and subjective criteria" might undermine the predictability of the legal order, in particular by limiting the contractual rights of private creditors. It also feared that the law might lead to (2) a lower degree of secondary market activity, which would reduce the price of sovereign debt instruments and increase the return on loans, which in turn would make restructuring harder. The first argument is void, since there does exist a well-established legal tradition to determine "illegitimate advantage." While a well-functioning secondary market is desirable, the second argument seems to ignore that the behavior of vulture funds imposes costs on distressed countries well beyond the benefits. In fact, they create huge inefficiencies and inequities in secondary markets that can cause the total implosion of SDR. The IIF also pleads for (3) international, market-based guidelines as put forward by the G20 (GriffithJones and Hertova 2013). Today, debtor countries can easily include into their bond contracts the CAC prototype drafted by the International Capital Market Association (ICMA). However, not only does CAC induce strategic behavior, some countries do not even include a CAC because it might increase interest rates.

But the vulture funds were not going to give in that easily. Since the attachment of payments to exchange bondholders seemed barred by the Belgian Law Against Vulture Funds, they tried to subvert the law by lobbying for another bill aimed at weakening sovereign immunity and strengthening the ability to seize diplomatic goods. In the nineteenth and first half of the twentieth century, state debtors were traditionally protected by sovereign immunity. After the second world war, sovereign immunity was restricted to non-commercial state activities, thus denying immunity for commercial activities such as borrowing money by issuing state debt. In the recent past, vulture funds have persistently, but relatively unsuccessfully, tried to attach the holdings of 
debtor states all over the world. If that strategy would become more successful, it would undermine the Belgian Law Against Vulture Funds. The reason is that the latter law is unclear as to whether it can be applied when the amounts attached in Belgium are less that the purchasing price paid by the creditor. The rationale of the law is indeed not to outlaw all claims made by vulture funds, but to limit enforcement in Belgium to the purchasing price. So, if a vulture fund could demonstrate that the attachments in Belgium, if paid to it, would not provide an "illegitimate advantage" since they are worth less the purchasing price of the bonds, it might seize some of the diplomatic assets in Belgium.

So, during the summer of 2015, a new piece of legislation was rushed through parliament. The "law aimed at inserting a new article 1412quinquies in the Judicial Code on the attachment of properties of foreign powers or public supranational or international organizations," hereafter the Diplomatic Immunities Law, ${ }^{25}$ was tabled on July 2, just a few days before the plenary vote on the Belgian Law Against Vulture Funds. In accordance with the UN Treaty of December 2, 2004, the Belgian law forbids the attachment of foreign state property that is used for non-commercial public purposes, unless the foreign government explicitly waives its immunity. However, the Belgian law also requires that the waiver is granted in a specific way. It is the latter clause that came under attack. The urgency procedure was invoked and approved. As a result, the first parliamentary debate already took place in the Justice Committee a few days later on July 7. An urgent advice was requested from the State Council, which came in on July 15 . On July 22 , the day after the national holiday which marks the traditional start of the parliamentary recess, the Justice Committee reconvened and adopted the text. During the debate in the committee, the need and legitimacy of the urgency procedure was questioned and heavily criticized. ${ }^{26}$ A meticulously amended version of the bill passed in the plenary session on July 24 . The law was published in the Belgian Gazette on September 3, 2015. It is fair to say that the Diplomatic Immunities Law was processed at parliamentary rocket speed.

Article 2 of the original Diplomatic Immunities Bill read as follows: " $\$ 1$. Without prejudice to the mandatory rules of supranational and international law, assets belonging to a state which are located on the territory of the Kingdom, including bank accounts which are there held or managed, which are used or intended to be used for non-commercial public service missions, including for the exercise of diplomatic or consular missions of the state, for the exercise of special missions, missions to international organizations, or delegation to the body of international organizations or conferences, may not be attached. $\$ 2$. By exception to $\$ 1$, assets belonging to a state mentioned under $\$ 1$ may be attached if one of the following conditions is fulfilled: $1^{\circ}$ if the state has explicitly agreed that this asset can be attached, $2^{\circ}[\ldots]^{\prime \prime}$

A sufficient condition for the attachment of diplomatic goods, including the bank accounts of embassies, would thus be the explicit agreement by the foreign state. This implies that there would be no requirement for a specific consent or waiver, contrary to what the Belgian Supreme Court had ruled in 2012 or what the United Nations Convention on Jurisdictional Immunities of States and Their Property had agreed upon in $2004{ }^{27}$ In other words, an explicit consent or general waiver, not a specific waiver, would be sufficient to warrant the attachment of diplomatic assets. Clearly, this would undermine the Belgian Law Against Vulture Funds, since it would become very hard to argue that the waiver contained in the Fiscal Agency Agreement of debt issuances prevents attachments. For instance, the waiver in the majority of Argentine bond contracts reads: “To the extent that the Republic or any of its [...] assets [...] shall be entitled [...] to any immunity from [...] jurisdiction [...] from attachment prior judgment, from attachment in aid of execution of judgment, from execution of a judgment [...] the Republic has irrevocably agreed not to claim and has irrevocably waived such immunity to the fullest extent permitted by the laws of such jurisdiction."

However, during the deliberations of the Justice Commission, an amendment was drafted and approved to replace the word "explicitly" by "explicitly and specifically." It follows that a state must agree with the attachment of diplomatic goods that are otherwise protected by sovereign immunity in a "specific" rather than a general way. This way, a new attack by the vulture funds was beaten off. Subsequently, they took to the Belgian Constitutional Court to fight the Diplomatic Immunities Law as well. ${ }^{28}$ In a recent ruling, ${ }^{29}$ the Constitutional Court decided that in accordance with the Treaty of Vienna of April 18, 1961, a specific waiver remains required for the attachment of goods for diplomatic purposes, but that in line with international law, a general waiver suffices for the attachment of non-diplomatic, non-commercial goods. The Court thus relaxes the rules of attachment as intended by the Belgian legislator.

\subsection{Limitations and improvements}

Resisting all lobbying efforts, the majority of Belgian legislators kept a firm and principled stance against the vulture funds. Hence, the Belgian law was widely applauded as an important step in the right direction. However, it failed its first major test. In 2016, Argentina chose to give in to the vulture funds, instead of paying its exchange bondholders attachment-free via a clearing house in Belgium. This decision disrupts any future cooperative debt restructuring that requires a haircut to restore economic health, since it encourages investors to 
hold out till court. As mentioned, timing may have been an issue. The law came too late for the former Argentine administration to pan out. Or does the Belgian law suffer other flaws, and if so, how can they be amended?

In contrast to conventional policy wisdom, settling with the vulture funds was not a matter of urgency. First, economic research has shown that the negative effects of a default on exports (Borensztein and Panizza 2010) and economic growth (Sturzenegger 2004; Panizza, Sturzenegger, and Zettelmeyer 2009: 681) are small and short-lived and that recovery is fast. Second, Argentina did receive foreign direct investments during the vulture era. ${ }^{30}$ Third, from the US $\$ 16.5$ billion of revenues raised by Argentine post-vulture bonds, US $\$ 12.3$ billion was paid to bondholders, leaving only a quarter for public investments or future pay-offs. ${ }^{31}$ Fourth, although the sovereign debt literature has long asserted that credit markets tend to "forgive and forget" (Borensztein and Panizza 2008), recent research has found that higher haircuts are associated with significantly higher subsequent bond yield spreads (Cruces and Trebesch 2013). To the extent that the vulture funds prohibited a timely return to normality, settling was the right thing to do. But with a 7.14\% interest rate on the new bonds, renewed borrowing is not exactly cheap for Argentina.

So why did the new Argentine government settle so hastily? Vote-maximizing domestic politicians have an clear self-interest in putting a financial conflict to an end, since a protracted debt crisis tarnishes their reputation with their voters (Bulow and Rogoff 1989; Cole and Kehoe 1998), who can pressure the government to resolve the crisis or face electoral defeat (Broner, Martin, and Ventura 2010). ${ }^{32}$ By ending the stalemate with the vulture funds, the new government regained full access to the international credit markets, which allows it to finance more public investments and spur economic growth.

Syndicated banks also have a financial interest to solve the crisis and regain business. Reportedly, the biggest winners of Argentina's return to the international financial markets are JP Morgan and Deutsche Bank (Millan 2016). Coincidentally, many top finance officials within the new Argentine administration worked at the former bank. Positively, the old boys' network may have quickly restored confidence in the Argentine state and thus lowered transaction costs in securing new loans. On the other hand, a bank syndicate is a cartel that may also raise the costs of borrowing at the expense of the tax payers. It certainly requires further financial research to assess the market-conformity of the terms of the new Argentine bonds.

The main obstacle for the Argentine government to use the Belgian bypass seems to be indirect contempt of the American court. Paying the Argentine exchange bondholders via Belgium would have been an act of willful disregard of the orders by the Southern District Court of New York, however absurd. Disobeying a court order is an offence that may carry sanctions, like the repatriation of money - to be made available to the vulture funds.

Moreover, also clearing houses may be held in contempt. The original wording of the Belgian Law Against Vulture Funds read as follows: "Regardless of the law applicable to the legal relationship with the debtor state, the Belgian public order opposes any order for payment or any measure of enforcement by a foreign verdict in order to obtain payment of an illegitimate advantage for a party that bought a loan or debt from a third party." This article would imply that it is illegal to make a payment to a vulture fund following a foreign court order or any other order. As a result, companies incorporated in Belgium also operating in foreign jurisdictions could get caught between two conflicting court decisions. Therefore, the following amendment was approved: "Regardless of the law applicable to the legal relationship between the creditor and the debtor state, no enforceable title can be obtained in Belgium, nor any measure of custody or enforcement can be taken in Belgium at the request of the creditor to obtain payment in Belgium if that payment purveys an illegitimate advantage as defined by law." The new text explicitly wants to prevent that a Belgium-based clearing house is confronted with a foreign court order that it cannot execute because it violates the Belgian public order, even if the court order has to be enforced abroad. Mutatis mutandis, Belgian courts can block payments in Belgium to vulture funds, while a foreign court order that endorses the claims by vulture funds cannot be enforced in Belgium. This clearly shows the need for an international solution, which is unlikely to succeed in the near future. Alternatively, if the Belgian model-law is adopted by other jurisdictions, it could strengthen the legal framework without the political difficulties of reaching worldwide consensus (Schwarcz 2015).

\section{Conclusion: The End of Vulture Funds?}

Many learned observers of the Argentine precedent have expressed fears over the economic fall-out of capitulating to the vulture funds. ${ }^{33}$ For sure, they won big time and the ratable payment interpretation of the pari passu clause is set to disrupt the orderly restructuring of sovereign debt for many decades, causing havoc especially to poor countries. The Argentine decision to pay gives a strong incentive to bondholders to stop at nothing but collecting the full value of their defaulted bonds. Since 2016, holding out has become a rational strategy for all bondholders confronted with a sovereign default. Ironically, it may well prove a self-defeating strategy since rational primary bondholders are no longer willing to settle or to sell their defaulted bonds to vulture funds for anything less than full value. However, this rationale does not apply to bondholders in urgent need of liquidity. 
The pivotal problem of SDR is the lack of a legal framework, unlike corporate restructuring. The contractual proposals to create a more orderly SDR process have so far turned out to be ineffective. Collective action clauses can still easily be circumvented by acquiring a strategic blocking minority and contractual sweeteners offer a too low return compared to holding out. A return to the conventional pari passu clause may weaken the position of vulture funds in court, but not their litigating behavior. The optimal solution for an orderly SDR process is an international bankruptcy procedure, which in turn is plagued by non-cooperative behavior of states.

The repair of the champerty defense and sovereign immunity could eliminate sovereign debt litigation and the related costs of protracted restructuring inflicted upon debtor states and exchange bondholders. Champerty is not the easiest of arguments though, since it requires proof of intent. By promoting fair instead of full repayment of public debt, the Belgian Law Against Vulture Funds builds on the champerty doctrine, but in a more pragmatic sense since it requires proof of the systematic use instead of intentional (ab)use of legal procedures. The law also meets the nine principles of the UN resolution on SDR. While restoring sovereign debt restructuring, sovereign immunity and debt sustainability, it also promotes transparency, impartiality and legitimacy via the use of courts, as well as negotiations in good faith and majority restructuring. If applied, it would mark the end of the realm of the vultures.

However, the Belgian Law Against Vulture Funds failed its first major test when Argentina decided to settle. The reasons are twofold. First, it remains in the interest of rational domestic politicians to end a financial crisis as soon as possible. Second, diverging views on the legitimacy of vulture funds may lead to contempt in court in other jurisdictions, making it costly for distressed countries to take the Belgian bypass. To be truly effective, the Belgian law has to be imposed on another state by its adoption in a multilateral international convention or by its enactment of a model law along the same lines (Mooney 2015: 235). Nevertheless, the Belgian initiative is an important step forward on the learning curve of SDR and may even set the norm for dealing with vulture funds in the future. It promotes and endorses debt sustainability as a legal principle (Bohoslavsky and Goldmann 2016), but also demonstrates - once again - the need of an international SDR legal framework (Li 2015).

\section{Acknowledgements}

We are grateful to Martin Guzman, Thomas Ulen, the participants at the 2016 Annual Law \& Economics Conference at the Universidad Torcuato di Tella as well as the anonymous referees for their valuable comments. Any errors remain our own.

\section{Notes}

\footnotetext{
${ }^{1}$ Adam Smith (1776), An Inquiry into the Nature and Causes of the Wealth of Nations, Book V, Chapter III: On Public Debt, Petersfield (Hampshire): Harriman House Ltd (2007), p. 608.

${ }^{2}$ In the Argentine 2001 default, almost 600,000 creditors from all over the world held 152 different debt instruments nominated in 6 currencies under the laws of 8 jurisdictions, according to The Economist (2005), A Victory by Default?, March 3. Available at: http://www.economist.com/node/3715779.

${ }^{3}$ For example, the total amount claimed by three vulture funds from the Democratic Republic of Congo in 2011 was equal to $85.57 \%$ of the public health budget or $41 \%$ of the education budget. See: http://www.11.be/artikels/item/ngo-s-gaan-mee-juridisch-gevecht-aantegen-aasgierfondsen\#ngo-actie.

${ }^{4}$ For a comprehensive overview of the Argentine financial crisis, see Guzman (2016).

${ }^{5} \mathrm{Harsh}$ as it may look at first sight, the $70 \%$ haircut was quite a reasonable proposal given that the Argentine economy had shrunk by about $70 \%$ in U.S. dollar terms.

${ }^{6}$ The 2005 Congress Law no. 26017, art. 2, Feb. 10, B.O. 30590 (Arg.) barred the Argentine government from renegotiating with holdout creditors without parliamentary approval and, by consequence, accepting any judgement from a foreign court ordering else.

${ }^{7}$ The Second District Court required Argentina to pay $100 \%$ of the (face value of) debt owed to the holdouts every time that it sought to pay what it owed to the exchange bondholders.

${ }^{8}$ Court of Appeals of Brussels, 9th Chamber (2004), Republic of Nicaragua vs. LNC Investment and Euroclear Bank, case no. 2003/KR/334.

${ }^{9}$ Belgian Chamber of Representatives (2004), Loi modifiant la loi du 22 mars 1993 relativeau statut et au contrôle desétablissements de crédit, la loi du 9 juillet 1975 relative au contrôle des entreprises d'assurances, la loi du 2 août 2002 relative à la surveillance du secteur financier et aux services financiers et la loi du 28 avril 1999 visant à transposer la Directive 98/26/CE du 19 mai 1998 concernant le caractère définitif du règlement dans les systèmes de paiement et de règlement des opérations sur titres, no. 4765 (C-2004/03482), art. 15.

${ }^{10}$ Argentine Law No. 26,984.

${ }^{11}$ For instance, $75 \%$ in euro-CAC's up to $85 \%$ for reserve matters. See, e.g. Haldane et al. (2004).

${ }^{12}$ These clauses can be included in the terms of the exchange bonds to strengthen the protection of bondholders, either by a reduction in the outstanding stock of debt (i.e. mandatory prepayment clauses) or by an accepted haircut in case of a new default (mandatory restatement of principal). See, e.g. Olivares-Caminal (2013).

${ }^{13}$ See, e.g. Principles Consultative Group (2013), Principles of Stable Capital Flows and Fair Debt Restructuring, Washington: Institute of International Finance. Available at: https://www.iif.com/file/4321/download?token=mBvJtcaR.
} 
${ }^{14}$ United Nations (2015), Resolution A/69/L.84 on “Basic Principles on Sovereign Debt Restructuring Processes”, New York: UN. Available at: http://unctad.org/meetings/en/SessionalDocuments/a69L84_en.pdf

${ }^{15}$ Second Circuit (1998), Case no. 194 F. 3d 363. In August 2004, the New York state legislators even amended N.Y. Judiciary Law 489 to completely eliminate the defense of champerty for debt purchases. See Blackman and Mukhi (2010).

${ }^{16}$ Assemblée Nationale (2006), Proposition de Loi no. 3214. Available at: http://www.assemblee-nationale.fr/12/propositions/pion3214.asp

${ }^{17}$ Stop Very Unscrupulous Loan Transfers from Underprivileged Countries to Rich, Exploitive (VULTURE) Funds Act (2009), H.R. 2932, 111th Cong. §2(8).

${ }^{18}$ Eligible for financing by the International Development Association (IDA).

${ }^{19}$ Debt Relief (Developing Nations) Act (2010), c. 22, §1(1)-(6).

${ }^{20}$ See, e.g. Panizza, Sturzenegger, and Zettelmeyer (2009): 671: "[I]nstitutional or legal changes in sovereign debt after the 1980's do not appear to have altered the relationship between economic and political variables and the probability of debt default."

${ }^{21}$ Belgian Chamber of Representatives (2008), Proposition de loi visant à empêcher la saisie ou la cession des fonds publics destinés à la cooperation internationale, notamment par la technique des fonds vautours, DOC 52 0762/001, Brussels. Available at: http://www.dekamer.be/FLWB/PDF/52/0762/52K0762001.pdf.

${ }^{22}$ Coalition of the Flemish North-South Movement 11.11.11 and its French-speaking counterpart CNCD. See: http://www.11.be/.

${ }^{23}$ Belgian Chamber of Representatives (2015), Projet de loi relative à la lutte contre les activités des fonds vautours, DOC 54 1057/005, Available at: http:/ /www.dekamer.be/FLWB/PDF/54/1057/54K1057005.pdf.

${ }^{24}$ Belgian Constitutional Court, Case no.6371: Appeal to repeal the law of July 12, 2015 against the activities of vulture funds, submitted on March 2, 2016 by NML Capital Ltd (corporation under Cayman Law). September 2017, the case was still pending.

${ }^{25}$ Belgian Chamber of Representatives (2015), Projet de loi insérant dans le Code judiciaire un article 1412quinquies régissant la saisie de biens appartenant à une puissance étrangère ou d̀ une organisation supranationale ou internationale de droit public. DOC 54 1241/001. Available at: http://www.lachambre.be/FLWB/PDF/54/1241/54K1241001.pdf.

${ }^{26}$ Belgian Chamber of Representatives, see: http:/ /www.dekamer.be/FLWB/PDF/54/1241/54K1241005.pdf.

${ }^{27}$ United Nations Convention on Jurisdictional Immunities of States and Their Property is available at: http://legal.un.org/ilc/texts/instruments/english/conventions/4_1_2004.pdf.

${ }^{28}$ Belgian Constitutional Court, case no. 6372.

${ }^{29}$ Belgian Constitutional Court, April 2, 2017, see: http://www.const-court.be/public/f/2017/2017-048f.pdf.

${ }^{30}$ For example, in July 2014, Chinese president Xi Jinping signed trade and investment agreements with Argentina worth US $\$ 7.5$ billion to develop energy and transport infrastructure projects. See, e.g. Gonzalez and Devereux (2014).

${ }^{31}$ US $\$ 9.3$ billion was used to pay off the vulture funds, who still hold out on US\$ 3.5 billion in claims. US\$ 4.65 billion was paid to Elliott Management and fellow hedge funds, i.e. $75 \%$ of the original US\$ 5.9 billion claim, yielding them a staggering $1180 \%$ profit. US\$ 3 billion was used to pay the exchange bondholders. The Central Bank foreign-currency reserves thus increased by US $\$ 4.2$ billion dollar to approximately US\$ 35 billion dollar.

${ }^{32}$ Yaeger (2016) remarked that the hold-out investors not only include some notorious vulture funds, but also a few wealthy Argentine citizens.

${ }^{33}$ See, e.g. Muse-Fisher (2014) and Guzman and Stiglitz (2016a).

\section{References}

Bai, James. 2013. “Stop Them Circling: Addressing Vulture Funds in Australian Law.” Sidney Law Review 35: 703-730.

Blackman, Jonathan I., and Rahul Mukhi. 2010. “The Evolution of Modern Sovereign Debt Litigation: Vultures, Alter Egos, and Other Legal Fauna." Law and Contemporary Problems 73: 47-61.

Bohoslavsky, Juan Pablo, and Matthias Coldmann. 2016. “An Incremental Approach to Sovereign Debt Restructuring: Sovereign Debt Sustainability as a Principle of Public International Law." Yale Journal of International Law 41 (2): 13-43.

Borensztein, Eduardo, and Ugo Panizza. 2008. “The Costs of Sovereign Default.” Washington: International Monetary Fund, IMF Working Paper 08/238.

Borensztein, Eduardo, and Ugo Panizza. 2010. “Do Sovereign Defaults Hurt Exporters?” Open Economies Review 21 (3): 393-412. Available at: https://www.imf.org/external/pubs/ft/wp/2008/wp08238.pdf.

Bosco, David. 2007. “The Debt Frenzy.” Foreign Policy 161: 36.

Broner, Fernando, Alberto Martin, and Jaime Ventura. 2010. “Sovereign Risk and Secondary Markets."American Economic Review 100 (4): 1523-1555.

Brooks, Skylar, Martin Guzman, Domenico Lombardi, and Joseph E. Stiglitz. 2015. “Identifying and Resolving Inter-Creditor and DebtorCreditor Equity Issues in Sovereign Debt Restructuring." Waterloo (Canada): Centre for International Covernance Innovation, CICI Policy Brief 52. Available at: https://www.cigionline.org/sites/default/files/pb_no53.pdf.

Broomfield, Elizabeth. 2010. "Subduing the Vultures: Assessing Covernment Caps on Recovery in Sovereign Debt Lititgation." Columbia Business Law Review 3: 473-527.

Buchheit, Lee C., and Ralph Reisner. 1988. "The Effect of the Sovereign Debt Restructuring Process on Inter-Creditor Relationships." University of Illinois Law Review 2: 493-509.

Buchheit, Lee C., and Mitu C. Culati. 2017. “Restructuring Sovereign Debt after NML v. Argentina.” Capital Markets Law Journal 12 (2): $224-238$.

Buchheit, Lee C., Anna Gelpern, Mitu C. Culati, Ugo Panizza, Beatrice Weder, and Jeromin Zettelmeyer. 2013. “Revisiting Sovereign Bankruptcy." Waterloo (Canada): Committee on International Economic Policy and Reform. Available at: http://papers.ssrn.com/sol3/papers.cfm?abstract_id=2354998.

Bulow, Jeremy, and Kenneth Rogoff. 1989. “Sovereign Debt: Is to Forgive to Forget?” American Economic Review 79 (1): 43-50.

Cantamutto, Francisco ]., and Daniel Ozarow. 2016. “Serial payers, serial losers? The political economy of Argentina's public debt." Economy and Society 45 (1): 123-147. 
Cole, Harold, and Patrick Kehoe. 1998. “Models of Sovereign Debt: Partial versus Ceneral Reputations.” International Economic Review 39 (1): 55-70.

Cruces, Juan J., and Christoph Trebesch. 2013. "Sovereign Defaults: The Price of Haircuts." American Economic Journal: Macroeconomics 5 (3): 85-117.

Das, Udaibir, Michael Papaioannou, and Christoph Trebesch. 2012. "Sovereign Debt Restructurings 1950-2010: Literature Survey, Data, and Stylized Facts." Washington: IMF, Working Paper WP/12/203. Available at: https://www.imf.org/external/pubs/ft/wp/2012/wp12203.pdf.

Eaton, Jonathan, and Mark Gersovitz. 1981. "Debt with Potential Repudiation: Theoretical and Empirical Evidence." Review of Economic Studies 48 (2): 289-309.

Eichengreen, Barry, and Ashoka Mody. 2000. “Would Collective Action Clauses Raise Borrowing Costs? - An Update and Additional Results." Washington DC: World Bank, Research Working Paper WPS 2363. Available at: http://documents.worldbank.org/curated/en/774531468766839033/Would-collective-action-clauses-raise-borrowing-costs-an-update-and-additional-results.

Conzalez, Pablo, and Charlie Devereux. 2014. “Xi Flies to Argentina with \$7.5 Billion in Tow.” Bloomberg News, July 18. Available at: http://www.bloomberg.com/news/articles/2014-07-18/xi-flies-to-argentina-with-7-5-billion-in-tow.

Griffith-Jones, Stephany, and Dagmar Hertova. 2013. “Growth-Linked Bonds." Journal of Institutional Comparisons 11 (3): 33-38.

Guzman, Martin. 2016. “An Analysis of Argentina's 2001 Default Resolution.” Waterloo (Canada): Centre for International Covernance Innovation, CICI Paper 110. Available at: https://www.cigionline.org/sites/default/files/documents/CICI\%2OPaper\%20No.110WEB_0.pdf.

Guzman, Martin, and Joseph E. Stiglitz. 2016a. "How Hedge Funds Held Argentina for Ransom." The New York Times, April 1. Available at: http://www.nytimes.com/2016/04/01/opinion/how-hedge-funds-held-argentina-for-ransom.html?_r=0.

Guzman, Martin, and Joseph E. Stiglitz. 2016b. “Creating a Framework for Sovereign Debt Restructuring that Works." In Too Little, Too Late: The Quest to Resolve Sovereign Debt Crises, edited by Martin Guzman, José Antonio Ocampo, and Joseph E. Stiglitz, 3-32. New York: Columbia University Press.

Guzman, Martin, and Joseph E. Stiglitz. 2016c. "A Soft Law Mechanism for Sovereign Debt Restructuring Based on the UN Principles." In International Policy Analysis, 1-12. Berlin/New York: Friedrich-Ebert-Stiftung. Available at: http://library.fes.de/pdf-files/iez/12873.pdf.

Haldane, Andrew G., Adrian Penalver, Victoria Saporta, and Hyun Song Shin. 2004. Optimal Collective Action Clause Thresholds. Washington: IMF, unpublished manuscript. Available at: https://www.imf.org/external/np/res/seminars/2004/60/pdf/haldan.pdf.

Howse, Robert. 2016. “Toward a Framework for Sovereign Debt Restructuring: What Can Public International Law Contribute?” In Too Little, Too Late: The Quest to Resolve Sovereign Debt Crises, edited by Martin Guzman, José Antonio Ocampo, and Joseph E. Stiglitz, 241-252. New York: Columbia University Press.

International Monetary Fund. 2014. Strengthening the Contractual Framework to Address Collective Action Problems in Sovereign Debt Restructuring. Washington: IMF, Staff report. Available at: https://www.imf.org/external/np/pp/eng/2014/090214.pdf.

International Capital Market Association. 2014. Standard Pari passu Provision for the Terms and Conditions of Sovereign Notes. Basel: ICMA. Available at: http://www.icmagroup.org/Regulatory-Policy-and-Market-Practice/Primary-Markets/collective-action/.

Krueger, Anne O. 2002. A New Approach to Sovereign Debt Restructuring. Washington: IMF. Available at: https://www.imf.org/external/pub$\mathrm{s} / \mathrm{ft} / \mathrm{exrp} / \mathrm{sdrm} / \mathrm{eng} / \mathrm{sdrm} . \mathrm{pdf}$.

Li, Yuefen. 2015. "The Long March Towards an International Legal Framework for Sovereign Debt Restructuring." Journal of Clobalization and Development 6 (2): 329-341.

Millan, Carolina. 2016. "JPMorgan's Big Bet on Argentina Is Paying Off." Bloomberg News, July 12. Available at: http://www.bloomberg.com/news/articles/2016-07-12/jpmorgan-s-big-bet-on-argentina-is-paying-off-as-bond-sales-boom.

Mooney, Charles W. 2015. "A No-Tribunal SDRM and the Means of Binding Creditors to the Terms of a Restructuring Plan." Journal of Clobalization and Development 6 (2): 215-238.

Muse-Fisher, John. 2014. "Starving the Vultures: NML Capital v. Republic of Argentina and Solutions to the Problems of Distressed-Debt Funds." California Law Review 102 (6): 1671-1725.

Olivares-Caminal, Rodrigo 2013. “The Pari Passu Clause in Sovereign Debt Instruments: Developments in Recent Litigation.”. In Sovereign Risk: A World Without Risk-Free Assets?. 121-128. Basel: Bank for International Settlements BIS papers no. 72. Available at: http://www.bis.org/publ/bppdf/bispap72u.pdf.

Panizza, Ugo, Federico Sturzenegger, and Jeromin Zettelmeyer. 2009. "The Economics and Law of Sovereign Debt and Default." Journal of Economic Literature 47 (3): 651-698.

Paulus, Christoph. 2012. Should Politics be Replaced by a Legal Proceeding?, 1-21. Paris: International Insolvency Institute. Available at: https://www.iiiglobal.org/sites/default/files/shouldpoliticsbereplacedbyalegalproceeding.pdf.

Porzecanski, Katia, Charlie Devereux, and Bob Van Voris. 2016. "Paul Singer Cuts Deal With Argentina After Ugly, 15-Year Dispute." Bloomberg News, February 29. Available at: http://www.bloomberg.com/news/articles/2016-02-29/argentina-reaches-4-65-billiondeal-with-main-holdouts.

Pottow, John A. E. 2013. "Mitigating the Problem of Vulture Holdout: International Certification Boards for Sovereign-Debt Restructurings." Texas International Law Review 49: 221-243.

Principles Consultative Croup. 2013. “Principles of Stable Capital Flows and Fair Debt Restructuring." Washington: Institute of International Finance. Available at: https://www.iif.com/file/4321/download?token=mBv]tcaR.

Samples, Tim. 2014. “Rogue Trends in Sovereign Debt: Argentina, Vulture Funds, and Pari Passu Under New York Law.” Northwestern Journal of International Law \& Business 35 (1): 49-86.

Schwarcz, Steven L. 2015. "Sovereign Debt Restructuring: A Model-Law Approach." Journal of Clobalization and Development 6 (2): 343-385.

Shalolashvili, Irakl. 2015. "An Analysis of the Argentine Bond Crisis." Univ. Miami Inter-American Law Review 46 (2): 179-208.

Smith, Adam. 1776. An Inquiry into the Nature and Causes of the Wealth of Nations. Petersfield (Hampshire): Harriman House Ltd (2007).

Schumacher, Julian, Christoph Trebesch, and Henrik Enderlein. 2014. "Sovereign Defaults in Court." Available at: https://papers.ssrn.com/sol3/papers.cfm?abstract_id=2189997.

Sturzenegger, Federico. 2004. "Toolkit for the Analysis of Debt Problems." Journal of Restructuring Finance 1 (1): 201-203.

The Economist. 2005. “A Victory by Default?" March 3. Available at: http://www.economist.com/node/3715779. 
Tomz, Michael. 2007. Reputation and International Cooperation: Sovereign Debt Across Three Centuries. Princeton: Princeton University Press. Turchi, Nathalie A. 2015. "Restructuring a Sovereign Bond Pari passu Work-Around: Can Holdout Creditors Ever Have Equal Treatment?" Fordham Law Review 83 (4): 2171-2215.

Venengo, Matías. 2014. “Argentina, Vulture Funds and the American Justice System." Challenge 57 (6): 46-55.

Weber, Axel, Jens Ulbrich, and Karsten Wendorff. 2011. "Safeguarding Financial Market Stability, Strengthening Investor Responsibility, Protecting Taxpayers. A Proposal to Reinforce the European Stability Mechanism Through Supplementary Bond Issuance Terms." Frankfurter Allgemeine Zeitung, March 11. Available at: https://www.bundesbank.de/Redaktion/EN/Downloads/Press/Current_Issues/safeguarding_financial_market_stability_strengthening_investor_responsibility_protecting_taxpayers.pdf?_blob=publicationFile.

Yaeger, Melissa. 2016. “Influence Abroad: American vulture funds feed on Argentina's debt crisis.” Sunlight Foundation, May 2. Available at: https://sunlightfoundation.com/blog/2016/05/02/influence-abroad-american-vulture-funds-feed-on-argentinas-debt-crisis/. 